\title{
Biotechnological activity of Spondias purpurea L.: Screening for antimicrobial activity and toxicity
}

\author{
Atividade biotecnológica de Spondias purpurea L.: Triagem da atividade antimicrobiana e \\ toxicidade
}

Gabriele Marisco $^{1 *}$; Regineide Xavier ${ }^{1}$; Renata Assunção ${ }^{1}$; Marina Amorim²; Roberta Souza ${ }^{1}$; Cristina Pungartnik ${ }^{3}$

${ }^{1}$ Universidade Estadual do Sudoeste da Bahia - UESB, Estrada Bem Querer, s/n, Vitória da Conquista - BA, 45083-900, gabrielemarisco@uesb.edu.br* (autor correspondente); https://orcid.org/0000-0002-8301-8673; regineide.xavier@uesb.edu.br; renata.correia@uesb.edu.br; robertasouza_bdo@hotmail.com

${ }^{2}$ Universidade Estadual de Campinas - UNICAMP, Cidade Universitária Zeferino Vaz - Barão Geraldo, Campinas - SP, 13083-970, marinaamorimo@gmail.com

${ }^{3}$ Universidade Estadual de Santa Cruz - UESC, Campus Soane Nazaré de Andrade, Rod. Jorge Amado, Km 16 - Salobrinho, Ilhéus - BA, 45662-900, cpungartnik@gmail.com

\section{Resumo}

No Brasil, Spondias purpurea L. é popularmente usada para tratamentos na medicina para problemas gastrointestinais, diabetes, colesterol alto e pressão alta. O objetivo deste estudo foi avaliar a atividade antimicrobiana e citotóxica de $S$. purpurea. O extrato bruto etanólico (CE) das folhas de $S$. purpurea e suas frações (FA, FB, FC e FC) foram testados como antifúngico e antibacteriano usando o teste de concentração inibitória mínima (CIM). Mutantes da levedura Saccharomyces cerevisiae relacionados com danos oxidativos (cttA, ctaA, sod14, sod2A) foram testados com CE. A letalidade e toxicidade foi determinada com o teste Artemia salina e Allium cepa. Os resultados mostram que cepas de fungos foram sensíveis a pelo menos umas das frações testadas. Entretanto, CE e FA foram os extratos com melhor ação antifúngica. As bactérias não foram sensíveis ao CE e frações. Os mutantes sod1 1 , sod2 $2 \Delta$ e ctt $\Delta$ apresentaram sensibilidade quando submetidos ao $\mathrm{CE}$. The $\mathrm{CE}$ e frações indicaram toxicidade moderada contra $A$. salina e $A$. cepa. Os resultados indicaram o uso de $S$. purpurea para o tratamento de infecções fúngicas causadas por Candida e possível atividade antitumoral; contudo, estudos in vivo devem ser conduzidos a fim de avaliar sua toxicidade e uso como agente terapêutico.

Palavras chave: atividade antifúngica, potencial medicinal, plantas brasileiras, toxicidade. 


\begin{abstract}
In Brazil, Spondias purpurea L. is commonly used in the system of medicine for treatment of gastric problems, diabetes, high cholesterol and high blood pressure. This study evaluated $S$. purpurea for its antimicrobial and cytotoxic activities. The ethanol crude extract (CE) from the leaves of $S$. purpurea and its four fractions (FA, FB, FC and FC) were assayed for antifungal activities and bactericidal activities using minimal inhibitory concentration (MIC). The yeast Saccharomyces cerevisiae mutant related oxidative stress (ctt $\Delta, \operatorname{cta} \Delta$, $\operatorname{sod} 1 \Delta, \operatorname{sod} 2 \Delta)$ was treated with CE. The lethality and toxicity, Artemia salina and Allium cepa were used. The results showed that the fungal strains tested were susceptible to at least one of the fractions tested. However, CE and FA were the best antifungal fractions. The bacteria showed no sensitivity against the crude extract and fractions. The mutants $\operatorname{sod} 1 \Delta$, sod2 $\Delta$ and ctt $\Delta$ showed sensitivity when submitted to the CE. The CE and fractions indicated moderate toxicity against $A$. salina and $A$. cepa. These results indicated the use of $S$. purpurea to treat fungal infections caused by Candida and possible antitumor activity; however, in vivo studies should be performed in order to assess its exploitation as therapeutic agent toxicity.
\end{abstract}

Keywords: antifungal activity, medicinal potential, brazilian plants, toxicity.

\title{
1. Introduction
}

It is of great interest that experimental studies of new drugs are conducted using ethnopharmacology, i.e., the study of biological activities of plants with medicinal use supported by popular knowledge (Rehecho et al., 2011), since this approach has a great potential to find new bioactive substances (Sousa et al., 2012).

Substances from plants are being used as alternatives in the treatment against different pathogens, as they produce several bioactive metabolites, which are sources for the synthesis of therapeutic drugs, pharmaceutical products (Newman \& Cragg, 2007; Moura et al., 2019).

The development of new antifungal and antibacterial agents, preferably naturally occurring with novel mechanisms of action, is an urgent medical need (Vicente et al., 2003; Guimarães et al., 2010). Currently, there are several test organisms to assess the bioactivity of plant extracts (Ostrosky et al., 2008).

Candida species have the ability to grow under various environmental conditions, are susceptible to drugs in varying ways, even within the same species, and certain species may develop resistance to common prescribed antifungal agents (Nordin et al., 2013). The yeast Saccharomyces cerevisiae is also an alternative tool for biological assays, as it mimics superior mammalian cells. This characteristic makes these cells important tools in research (Treusch et al., 2011). There are several methods that can be used to predict the in vitro sensitivity of bacteria to antimicrobial agents. Currently, these methods have been widely used in research looking for new antimicrobial agents. To quantitatively assess the in vitro activity of an 
antimicrobial agent against a certain bacterial isolate, the Minimum Inhibitory Concentration (MIC) can be determined (Balouiri et al., 2016).

The search for substances with potentially cytotoxic and anticancer activity has always been a priority for the medicinal chemistry and a large number of different approaches are being used in this search. However, the discovery of selective antitumor substances remains a goal in cancer research (Hoelder et al., 2012). The A. salina Leach (brine shrimp) is well correlated with antitumor activity (cytotoxicity) and can be used to monitor the activity of bioactive natural products (Arcanjo et al., 2012). The toxicity of a plant can be assessed in vitro relatively easily using the $A$. cepa test. In this test, the effect of the toxic substance is evidenced by macroscopic changes such as color, shape, size and root deformity and microscopic changes such as changes in the mitotic index and chromosomal and interphasic aberrations, in addition to its ease and speed of execution, is a reliable test (Arrares \& Longhin, 2012).

S. purpurea L. which belongs to the Anacardiaceae family is widely found in the northeastern part of Brazil (Ceva-antunes et al., 2006). This plant is popularly known as "seriguela", which is used in the Brazilian folk medicine (Engels et al., 2012) and has been described with antifungal and antibacterial activity (Bautista-Baños et al., 2000; Pizana et al., 2010; Miranda-Cruz et al., 2012). Hence, this study aimed to investigate the in vitro antifungal activity and antibacterial, and antitumor/cytotoxic activities of ethanol crude extract and its derived fractions of $S$. purpurea.

\section{Material and Methods}

\section{Extracts Preparation}

The plant S. purpurea was collected from Bahia. Voucher specimens were identified and deposited in the herbarium at UESB (number 6457). The leaves were extracted with ethanol, the crude extract $(\mathrm{CE})$. One gram of $\mathrm{CE}$ was fractionated based on the polarity change (Harborne, 1984); the following ratios of solvent combinations were sequentially used in the elution process; chloroform 100\%, chloroform: methanol 3:1; ethyl acetate $100 \%$. This fractionation resulted in four fractions [chloroform fraction (FA), chloroform-methanol fraction (FB), methanol extract (FC) and ethyl acetate fraction (FD)]. The solvent was removed by rotary evaporation and the extracts were dissolved in ethanol for bioassay.

\section{Antimicrobial Test}




\section{Micro-organisms}

Nine strains of bacteria used were Enterecoccus faecalis (ATCC29212), Enterecoccus faecalis (ATCC51299), Escherichia coli (ATCC 35218), Escherichia coli (ATCC 25922), Klebsiella pneumoniae (ATCC 700603), Staphylococcus aureus (ATCC25921), Staphylococcus aureus (ATCC43300), Pseudomonas aeruginosa (ATCC27853), Staphylococcus saprophyticus (ATCC35552) and five fungal Candida Albicans (ATCC 10231), C. krusei (ATCC 6258), C. albicans (ATCC 90028), C. parapsilosis (ATCC 90018) and C. parapsilosis (ATCC 22019). All bacterial strains were cultivated in Mueller Hinton Agar, while fungi were cultivated in RPMI 1640 medium.

\section{Broth Microdilution Assay}

The minimum inhibitory concentration (MIC) and minimum bactericidal or fungicidal concentration (MBC/MFC) were determined by the micro broth dilution method (NCCLS, 2007) in Mueller Hinton (MH) or RPMI 1640 medium (NCCLS, 2002). To determine MIC, the bacteria cells $\left(10^{3} \mathrm{UFC} / \mathrm{mL}\right)$ and yeast cells $\left(10^{6} \mathrm{UFC} / \mathrm{mL}\right)$ were inoculated in 96-well micro dilution plates in the presence of crude extract and fractions at $62.5-1000 \mu \mathrm{g} / \mathrm{mL}$ concentrations. After $24 \mathrm{~h}$ of incubation at $37{ }^{\circ} \mathrm{C}$ for bacteria and $28{ }^{\circ} \mathrm{C}$ for fungi, the lowest concentration showing no visible growth was considered as the MIC and the inhibitory concentration of $50 \%$ growth (IC 50\%), defined as the lowest concentration of extract that can inhibit $50 \%$ of visible microbial growth, has been determined. In cases of complete growth inhibition, for the determination of $\mathrm{MBC} / \mathrm{MFC}$ and to define the lowest extract concentration that could completely eliminate the microorganism, it was confirmed by re-inoculation in $\mathrm{MH}$ and Sabouraud Dextrose Agar, in which there was no visible growth. Controls on growth, sterility of the medium, sterility of the extract, as well as negative (at the same concentrations of solvents) and positive controls (riphampicin $45 \mu \mathrm{g} / \mathrm{mL}$ and amphotericin B at $10 \mu \mathrm{g} / \mathrm{mL}$ ) were simultaneously conducted. All trials were performed in triplicate.

\section{Saccharomyces cerevisiae Test}

The yeast $S$. cerevisiae mutant related oxidative stress $(\operatorname{ctt} \Delta, \operatorname{cta} \Delta, \operatorname{sod} 1 \Delta$ and $\operatorname{sod} 2 \Delta)$ was treated for $24 \mathrm{~h}$ with CE of S. purpurea leaves, in concentrations ranging from 7, 14 and 21 $\mathrm{mg} / \mathrm{mL}$. The cells were appropriately diluted (five serial 1:10 dilutions) and $5 \mu 1$ of each dilution was plated on YPD medium (2\% glucose and peptone, $1 \%$ yeast extract) in drop test and incubated at $30^{\circ} \mathrm{C}$ for 2-3 days. The photographs represent one of at least three similar triplicates. 


\section{Bioassay with Artemia salina}

The assessment of bioactivity of extract was carried out following the methodology described by Meyer et al. (1982) with modifications. In order to obtain crustacean cysts, it was incubated in sea water at room temperature, under direct light, for 24-26 h. The preparation of solutions with different concentrations $(1-1000 \mu \mathrm{g} / \mathrm{mL})$ of CE was performed by diluting the working solution in sea water. These solutions were dispensed in 24-well plates to which ten nauplii have been added, and plates were incubated at room temperature, under direct light. After $24 \mathrm{~h}$, the number of survivors was counted so as to determine the lethal concentration capable of eliminating $50 \%$ of organisms $\left(\mathrm{LC}_{50}\right)$. Ethanol was the negative control $(1 \%)$ and positive controls were $\mathrm{K}_{2} \mathrm{Cr}_{2} \mathrm{O}_{7}(0.33 \mathrm{mM})$. The assays were performed in triplicate. $\mathrm{LC}_{50}$ was calculated using the Probit method (BioStat, 2009) with a 95\% confidence interval.

\section{Bioassay with Allium cepa}

The six bulbs of $A$. cepa were treated with the leaves extracts at $1-100 \mu \mathrm{g} / \mathrm{mL}$ concentrations of EC. The test tubes were kept in at room temperature. Several of the newly formed root tips were then cut from each bulb and examined for any visible morphological abnormalities. The bulbs with satisfactory root lengths $(2-2.5 \mathrm{~cm})$ were used in the study, while those with exceptionally long or short roots were discarded (on average 2-3 bulbs). Therefore, individual set of five bulbs were used for each extract sample. Water was used as a negative control. After $24 \mathrm{~h}$ of exposure, several root tips were removed from the bulbs, fixed in $3: 1(\mathrm{v} / \mathrm{v})$ ethanol: glacial acetic acid and stored overnight at $4{ }^{\circ} \mathrm{C}$. The next day they were placed in $70 \%$ (v/v) aqueous alcohol and refrigerated until used. An average of five slides was made for each bulb using five root tips which hydrolyzed in $1 \mathrm{~N}$ hydrochloric acid $(\mathrm{HCl})$ for $3 \mathrm{~min}$ and microscope slides were prepared by squashing the stained root tips in $2 \%(\mathrm{w} / \mathrm{v})$ acetic orcein. Five slide was prepared per bulb, and each slide was examined using at a total magnification of $40 \times 10$. Were used for determination of cytotoxicity the mitotic index (MI) calculated as the ratio between the number of mitotic cells and the total number of cells scored and expressed as percentage. Statistical analyses were performed using the assistant software program. The mitotic index compared using analysis of variance (ANOVA) to confirm the variability of the data and validity of results. Differences between corresponding controls and exposure treatments were considered statistically significant at $\mathrm{p}<0.05$.

\section{Results}


In this study, the fungal growth inhibition for the extract and fractions was measured and represented in Table 1. Considering the reading of IC 50\%, three extracts are regarded as very important against at least one organism. However, we can highlight that Candida krusei was the most sensitive fungus in this study with the highest growth inhibition for $\mathrm{CE}$ and fractions $\mathrm{A}$ and $\mathrm{C}$ together can promote synergy and enhance the activity. However, regarding action, fraction A is highlighted, the fraction was active against Candida strains, whereas fractions B and $\mathrm{D}$ did not show any activity.

Table 1. The MIC and $\mathrm{IC}_{50}$ values of Spondias purpurea ethanol crude extract (CE) and fractions.

\begin{tabular}{ccccccc}
\hline \multirow{2}{*}{ Fungi } & \multicolumn{6}{c}{ MIC/IC50 (mg/mL) } \\
\cline { 2 - 7 } & CE & $\begin{array}{c}\text { Fraction } \\
\text { A }\end{array}$ & $\begin{array}{c}\text { Fraction } \\
\text { B }\end{array}$ & $\begin{array}{c}\text { Fraction } \\
\text { C }\end{array}$ & $\begin{array}{c}\text { Fraction } \\
\text { D }\end{array}$ & $\begin{array}{c}\text { Amphotericin } \\
\text { B }\end{array}$ \\
\hline $\begin{array}{c}\text { Candidaalbicans } \\
\text { (10231) }\end{array}$ & $-/ 0.5$ & $-/ 1$ & $-/-$ & $-/-$ & $-/-$ & 0.01 \\
$\begin{array}{c}\text { Candida krusei } \\
\quad(6258)\end{array}$ & $1 / 0.5$ & $0.5 / 0.25$ & $-/-$ & $0.5 / 0.25$ & $-/-$ & 0.01 \\
$\begin{array}{c}\text { Candida albicans } \\
\quad(90028)\end{array}$ & $-/ 1$ & $-/-$ & $-/-$ & - & - & 0.01 \\
$\begin{array}{c}\text { Candida parapsilosis } \\
\quad(90018)\end{array}$ & $-/-$ & $-/ 0.5$ & $-/-$ & $-/-$ & $-/-$ & 0.01 \\
$\begin{array}{c}\text { Candida parapsilosis } \\
\text { (22019) }\end{array}$ & $-/-$ & $-/ 1$ & $-/-$ & $-/-$ & $-/-$ & 0.01 \\
\hline
\end{tabular}

However, none of the nine evaluated bacteria showed sensitivity in the presence of EC and fractions of $S$. purpurea.

One investigated the oxidant activity of $\mathrm{CE}$ in yeast mutants related to deficiency in oxidative stress $(\operatorname{ctt} \Delta, \operatorname{cta} \Delta, \operatorname{sod} 1 \Delta$ and $\operatorname{sod} 2 \Delta)$. And observed that this plant has antifungal activity related to the damage involved (Figure 1), as can be noted by the sensitivity of the mutants $\operatorname{sod} 1 \Delta, \operatorname{ctt} \Delta, \operatorname{sod} 2 \Delta$ in concentration of $21 \mathrm{mg} / \mathrm{mL}$.

\begin{tabular}{|c|c|c|c|c|}
\hline WT & $\operatorname{sod} 1 \Delta$ & sod2 $\Delta$ & $\operatorname{cta} \Delta$ & \\
\hline 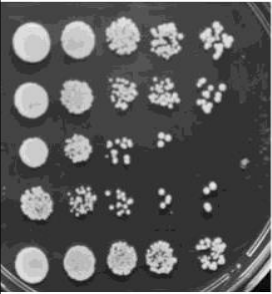 & $\begin{array}{ccccc}0 & 0 & 0 & 0 & 0 \\
0 & 0 & 0 & 0 & 0 \\
\ddots & 0 & . & 0\end{array}$ & 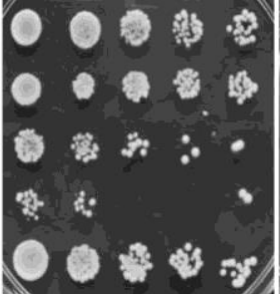 & 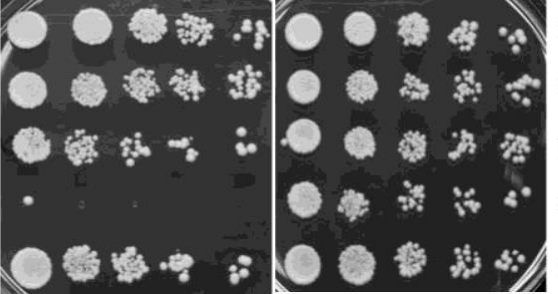 & $\begin{array}{l}\text { control } \\
7 \mathrm{mg} \\
14 \mathrm{mg} \\
21 \mathrm{mg}\end{array}$ \\
\hline
\end{tabular}

Figure 1. Drop test of the sensitivity of the mutants against the ethanol crude extract (CE) of $S$. purpurea. 
This study of $S$. purpurea showed biologic activity in this bioassay of $A$. salina. $\mathrm{LC}_{50}$ values for evaluated extracts are shown in Table 2. FA, FB, FD and CE showed biological activity $\mathrm{LC}_{50}$ below $500 \mu \mathrm{g} / \mathrm{mL}$, thus indicating toxicity. FC showed denote moderate toxicity when compared to the standards described by Meyer et al. (1982).

Table 2. Illustration of $\%$ age mortality of brine shrimps at different concentrations of extract and fractions and respective LC50 values using Probit.

\begin{tabular}{|c|c|c|c|c|c|}
\hline \multicolumn{6}{|c|}{$\%$ Mortality at various concentrations } \\
\hline Extracts & $\begin{array}{c}1000 \\
\mu \mathrm{g} / \mathrm{mL}(\%)\end{array}$ & $\begin{array}{c}100 \mu \mathrm{g} / \mathrm{mL} \\
(\%)\end{array}$ & $\begin{array}{c}10 \mu \mathrm{g} / \mathrm{mL} \\
(\%)\end{array}$ & $\begin{array}{c}1 \mu \mathrm{g} / \mathrm{mL} \\
(\%)\end{array}$ & $\begin{array}{c}\mathrm{LC}_{50} \\
(\mu \mathrm{g} / \mathrm{mL})\end{array}$ \\
\hline $\mathrm{CE}$ & 100 & 100 & 10 & 3 & 30 \\
\hline FA & 100 & 100 & 63 & 0 & 9 \\
\hline FB & 100 & 40 & 16 & 13 & 130 \\
\hline $\mathrm{FC}$ & 70 & 43 & 36 & 10 & 509 \\
\hline FD & 100 & 100 & 40 & 26 & 15.6 \\
\hline
\end{tabular}

CE (crude extract), FA (Fraction A), FB (Fraction B), FC (Fraction C), FD (Fraction D)

The cytotoxicity was emphasized by the decrease of the Mitotic Index (MI) in the concentrations of $100 \mu \mathrm{g} / \mathrm{mL}$ (Table 3).

Table 3. Treatments and number of cells in the cell cycle (interphase, prophase, metaphase, anaphase, telophase) in root tips of A. cepa treated with the extract of S. purpurea.

\begin{tabular}{|c|c|c|c|c|c|c|}
\hline \multirow{2}{*}{$\begin{array}{c}\text { EC } \\
\text { concentration }\end{array}$} & \multirow{2}{*}{$\begin{array}{c}\text { Interphas } \\
\text { e cells }\end{array}$} & \multicolumn{4}{|c|}{ Division cells } & \multirow{2}{*}{$\begin{array}{c}\text { Mitotic } \\
\text { index } \\
(\%)\end{array}$} \\
\hline & & Prophase & Metaphase & Anaphase & Telophase & \\
\hline Control & 4620 & 3.049 & 1.200 & 628 & 503 & $53.8 \%$ \\
\hline $100 \mu \mathrm{g} / \mathrm{mL}$ & 8096 & 1.100 & 321 & 273 & 210 & $19.04 *$ \\
\hline $10 \mu \mathrm{g} / \mathrm{mL}$ & 7308 & 1.593 & 484 & 342 & 273 & $26.92 \%$ \\
\hline $1 \mu \mathrm{g} / \mathrm{mL}$ & 6680 & 1.991 & 608 & 399 & 322 & $33.2 \%$ \\
\hline
\end{tabular}

* Difference between corresponding controls and exposure treatments were considered statistically significant at $\mathrm{p}<0.05$.

\section{Discussion}


The extract and fractions showed antifungal activity, these results are important, considering that the main group of fungi that cause opportunistic infections in humans is related to the genus Candida. This genus causes invasive infections that are associated with high morbidity and high mortality in affected patients. The appearance of these infections may be related to the resistance of these microorganisms to conventional antifungals (Viera \& Santos, 2017), and currently multidrug-resistant microorganisms have been reported, especially in immunosuppressed individuals, being a major public health problem, so it is essential to search by alternative therapies, preferably naturally occurring with new mechanisms of action (Chatterjee et al., 2016; Vicente et al., 2003).

Studies by Marisco et al. (2017) report the antifungal activity of these crude extract and fraction against Moniliophthora perniciosa, plant pathogenic fungus, suggesting that activity with the presence of terpenoids; the major components were identified as spathulenol $(14,2 \%)$, linolenic acid (8.4\%), trans-caryophyllene (6,9\%) and alpha-muurolene (6,9\%). Phytochemical studies showed the relation of antifungal activity with in the presence of terpenoids, thus exhibiting excellent activity against $C$. albicans yeast and hyphal form (Zore et al., 2011).

However, none of the nine evaluated bacteria showed sensitivity in the presence of EC and fractions of $S$. purpurea. These data differ from results obtained by Caceres et al. (1990), who used leaves; however, the dose employed for inhibiting the sensitivity was $10 \mathrm{gm} / \mathrm{ml}$ in Escherichia coli, Shigella flexneri and Salmonella typhi. In the study by Miranda-Cruz et al. (2012) leaves showed activity against Bacillus cereus at a dose of $7.5 \mathrm{mg} / \mathrm{mL}$. In the results shown by Santos et al (2017), the aqueous extract of this plant showed antibacterial activity, with an inhibition halo and MIC against the bacteria $S$. aureus and E. coli. According to Ríos $\&$ Recio (2005), when fractions and compounds have no activity, rather than invalidating the results, this should confirm the known anti-infection properties of the plant.

One investigated the oxidant activity of CE in yeast mutants related to deficiency in oxidative stress $(c t t \Delta, \operatorname{cta} \Delta, \operatorname{sod} 1 \Delta$ and $\operatorname{sod} 2 \Delta)$. These data corroborate studies found by Marisco et al. (2017), who indicates that oxidative activity via free radical production.

This study of $S$. purpurea showed toxicity (FC) when compared to the standards described by Meyer et al. (1982). Similar tests in S. purpurea were reported and it was observed that the ethanol extract of the leaves exposed for $48 \mathrm{~h}$ showed toxic activity against $A$. salina (Dantas, 2012), but the seeds of this plant showed no toxicity (Fonseca et al., 2013). In the study by Santos et al. (2017), the aqueous extract showed toxicity at the dose of $10 \mu \mathrm{g} / \mathrm{mL}$.

Studies showed that secondary metabolites may be toxic, thus plants in toxicity studies are necessary (Hullatti \& Murthy, 2010; Dutra et al., 2012). The A. salina bioassay to determine 
biological activity of medicinal plants commonly used by different people and ethnic groups is useful to evaluate their potential therapeutic indications and safety profile (Arcanjo et al., 2012).

Substances submitted to A. salina bioassay, which led to the death of half of the specimens at a lethal concentration of up to $1000 \mu \mathrm{g} / \mathrm{mL}$ (LC50), are considered active, and thus a good potential for antitumor activity (McLaughlin et al., 1998), and to evaluate the use of medicinal plants (Lira et al., 2014; Jeda et al., 2014). Therefore, it represents an increase in assessing new drugs and developing new medicines (Arcanjo et al., 2012).

The inhibition of cell division observed through the values of the mitotic index in $S$. purpurea demonstrates that this plant has potential for antiproliferative capacity. This response may be associated with the presence of terpenes detected in phytochemical analysis performed with the extract of $S$. purpurea (Marisco et al., 2017).

The analysis of the mitotic index is important because it allows to verify the interference of compounds produced by plants in the cell proliferation of many species (Dias et al., 2014). This ability to reduce the mitotic index is desirable for extracts for the purpose of use as anti carcinogenic, since they negatively interfere with cell proliferation (Sturbelle et al., 2010) and the $A$. cepa plant test system is one of the most used, since, among other advantages, it offers a good correlation with results of mammalian test systems (Herrero et al., 2012).

\section{Conclusion}

The $S$. purpurea in this study exhibited good antifungal activity and capacity promising natural bioactive agent; however, it did not show any against the tested bacteria. Based on the results obtained, one suggests the isolation of these components to evaluate the antifungal activity or to determine if there is synergy between the major components. Furthermore, the development of a biotechnological product with therapeutic action against Candida sp. can be produced, even more with the presence of multiresistant strains.

In addition, the studies on antitumor activity deserve attention after the results of A. salina and A.cepa. Thus, it is suggested that in vivo toxicity and evaluate the antitumor activity tests be conducted.

\section{Acknowledgment}

This study was financed by the Conselho Nacional de Desenvolvimento Científico e Tecnológico (CNPq) - Finance Code Universal 01/2016 - Faixa A 424774/2016-0. 


\section{References}

Arcanjo, D.D.R.; Albuquerque, C.M.; Melo-Neto, B. et al. (2012). Bioactivity evaluation against Artemia salina Leach of medicinal plants used in Brazilian Northeastern folk medicine. Brazilian Journal of Biology, 72, p. 505-9. https://doi.org/10.1590/S1519-69842012000300013

Arrares, A.I.O.M. \& Longhin, S.R. (2012). Otimização de ensaio de toxicidade utilizando o bioindicador Allium cepa como organismo teste. Enciclopédia Biosfera, v.8, n.14, p.1959-1972.

Balouiri, M.; Sadiki, S.K.; Ibnsouda, S.K. (2016). Methods for in vitro evaluating antimicrobial activity: a review Journal of Pharmaceutical Analysis. 6, p. 71-79. https://doi.org/10.1016/j.jpha.2015.11.005

Caceres, A.; Cano, O.; Samayoa, B. et al. (1990). Plants used in Guatemala for the treatment of gastrointestinal disorders screening of 84 plants against enterobacteria. Journal of Ethnopharmacology, 30, p. 55-73. https://doi.org/10.1016/0378-8741(90)90017-N

Ceva-antunes, P.M.N.; Ribeiro, H.; Silva, A.S. et al. (2006). Analysis of volatile composition of siriguela (Spondias purpurea L.) by solid phase microextraction (SPME). LWT, 39, p.436442. https://doi.org/10.1016/j.lwt.2005.02.007

Chatterjee, M., Anju, C.P.; Biswas, L. et al. (2016). Antibiotic resistance in Pseudomonas aeruginosa and alternative therapeutic options. International Journal of Medical Microbiology, 306, p 48-58. https://doi.org/10.1016/i.ijmm.2015.11.004

Dantas, A.M. (2012). Avaliação da Toxicidade e Atividade Antiulcerogênica das Folhas de Spondias purpurea L. Trabalho de Conclusão de Curso (Graduação em Farmácia) Universidade Estadual da Paraíba, Brasil. 23p. Disponível em: http://dspace.bc.uepb.edu.br/jspui/handle/123456789/318. Acessado em 11 de outubro de 2020.

Dias, M. G; Canto-Dorow, T. S.; Coelho, A. P. D. et al. (2014). Efeito genotóxico e antiproliferativo de Mikania cordifolia (L. f.) Willd. (Asteraceae) sobre o ciclo celular de Allium cepa L. Revista Brasileira de Plantas Medicinais, 16, p. 202-208. https://doi.org/10.1590/S1516-05722014000200006

Dutra, R.C.; Pittella, F.; Dittz, D. et al. (2012). Chemical composition and cytotoxicity activity of the essential oil of Pterodon emarginatus. Brazilian Journal of Pharmacognosy, 22, p. 971978. https://doi.org/10.1590/S0102695X2012005000042

Engels, C.; Gräter, D.; Esquivel, P. et al. (2012). Characterization of phenolic compounds in jocote (Spondias purpurea L.) peels by ultra high-performance liquid chromatography/electrospray ionization mass spectrometry. FRIN, 46, p.557-562. https://doi:10.1016/j.foodres.2011.04.003

Fonseca, R.C.; Souza, N.A.; Cristina, T. et al. (2013). Assessment of toxic potential of Cerrado fruit seeds using Artemia salina bioassay. Food Science and Technology, 33, p. 251-256. https://doi.org/10.1590/S0101-20612013005000032 
Guimarães, D.O.; Momesso, L.S.; Pupo, M.T. (2010). Antibióticos: Importância Terapêutica e Perspectivas para a Descoberta e Desenvolvimento de Novos Agentes. Revista Química Nova, 33, p.667-679. https://doi.org/10.1590/S0100-40422010000300035

Harborne, J. B. (1984). Phytochemical methods: A guide to modern techniques of plant analysis. Chapman an. ed. London, 150p. https://doi.org/10.1046/j.1365-3059.1999.00318.x

Hoelder, S.; Clarke, P. A.; Workman, P. (2012). Discovery of small molecule cancer drugs: successes, challenges and opportunities. Molecular Oncology, 6, p.155-176. https://doi:10.1016/j.molonc.2012.02.004

Herrero, O.; Pérez Martín, J.M.; Fernández P.F. et al. (2012). Toxicological evaluation of three contaminants of emerging concern by use of the Allium cepa test. Mutation Research, 743. p. 20-24. https://doi:10.1016/j.mrgentox.2011.12.028

Hullatti ${ }_{2}$ K.K. \& Murthy, U.D. (2010). Activity Guided Isolation of Cytotoxic Compounds from Indian Medicinal Plants Using BSL Bioassay. Journal of Current Pharmaceutical Research, 1, p.16-18. https://portal.issn.org/resource/ISSN/0976-3171\#

Jeda, L.A.; Olga, N.O.; Mylene, U.M. (2014). Brine Shrimp (Artemia salina) Bioassay of the medicinal plant Pseudelephantopus spicatus from Iligan City, Philippines. International Research Journal of Biological Sciences, 3, p. 47-50. http:/www.isca.in/IJBS/v3i9.php

Lira, D.N.; Uddin, A., Uddin, M. et al. (2014). Assessment of cytotoxic activities of Phyllanthus amarus and Monstera deliciosa. Journal of Appied Pharmaceutical Science, 4, p.110-113. https://doi:10.7324/JAPS.2014.40719

Marisco, G.; Santos, R.X.; Aguiar, R. et al. (2017) Antifungal Potential of Terpenes from Spondias Purpurea L. Leaf Extract against Moniliophthora Perniciosa that causes Witches Broom Disease of Theobroma Cacao. International Journal Complementary Alternative Medicine, 1, p 1-7. https://doi:10.15406/ijcam.2017.07.00215

McLaughlin, J.L.; Rogers, L.L.; Anderson, J.E. (1998). The Use of Biological Assays to Evaluate Botanicals. Drug Information Journal, 32, p. 513-524. https://doi:10.1177/009286159803200223

Meyer, B.N.; Ferrigni, N.R.; Putnam, J.E. et al. (1982). Brine shrimp: a convenient general bioassay for active plant constituents. Planta medica, 45, p. 31-34. https://doi:10.1055/s-2007$\underline{971236}$

Miranda-Cruz, E.; Espinosa-Moreno, J.; Centurión-Hidalgo, D. et al. (2012). Actividad antimicrobiana de extractos de Psidium friedrichsthalianum L., Pterocarpus hayesii L., Tynanthus guatemalensis L. y Spondias purpurea L. Boletim Latinoamericano y del Caribe de Plantas Medicinales y Aromáticas, 11, p. 354-361. https://pesquisa.bvsalud.org/portal/resource/pt/lil-648053

Moura, A.C.; Benvegnú, D.M.; Brito, G.C. et al. (2019). Atividade antibacteriana de extrato aquoso da casca de noz-pecã [Carya illinoinensis (wangenh.) c. koch]. Faz Ciência, 21, p. 88101. 
NCCLS. (2002). Reference Method for Broth Dilution Antifungal Susceptibility Testing of Yeasts, Approved Standard - Second edition. NCCLS document M 27- A2. NCCLS, Wayne, Pennsylvania, USA. v. 22, n. 15, 51p. Disponível em: www.nccls.org. Acessado em 10 de outubro de 2020.

NCCLS. (2007). Performance Standards for Antimicrobial Susceptibility Testing; Seventeenth Informational Supplement. NCCLS document M 100-S17. NCCLS, Wayne, Pa. Disponível em: http://file.qums.ac.ir/repository/mmrc/clsi\%202017.pdf. Acessado em 10 de outubro de 2020.

Newman, D.J.; Cragg, G.M. (2007). Natural products as sources of new drugs over the last 25 years. Journal of Natural Products, 70, p. 461-77. https://doi.org/10.1046/j.1469$\underline{0691.2003 .00489 . x}$

Nordin, M.A.F.; Wan Harun, W.H.A.; Abdul Razak, F. (2013). Antifungal susceptibility and growth inhibitory response of oral Candida species to Brucea javanica Linn. Extract. BMC complementary and alternative medicine, 13, p. 1-8. https://doi:10.1186/1472-6882-13-342

Ostrosky, E.A. Mizumoto, M. K.; Lima, M.E.L. et al. (2008). Métodos para avaliação da atividade antimicrobiana e determinação da Concentração Mínima Inibitória (CMI) de plantas medicinais. Revista Brasileira de Farmacognosia, 18, p. 301-307. doi.org/10.1590/S0102$\underline{695 \times 2008000200026}$

Rehecho, S.; Uriarte-Pueyo, I.; Calvo, J. et al. (2011). Ethnopharmacological survey of medicinal plants in Nor-Yauyos, a part of the Landscape Reserve Nor-Yauyos-Cochas, Peru. Journal of Ethnopharmacology, 133, p.75-85. https://doi:10.1016/j.jep.2010.09.006

Ríos, J.L. \& Recio, M.C. (2005). Medicinal plants and antimicrobial activity. Journal of ethnopharmacology, 100, p. 80-4. https://doi:10.1016/j.jep.2005.04.025

Sousa, Z.L.; Oliveira, F.F.; Conceição, A.O. et al. (2012). Biological activities of extracts from Chenopodium ambrosioides Lineu and Kielmeyera neglecta Saddi. Annals of clinical microbiology and antimicrobials, 11, p. 1-7. https://doi:10.1186/1476-0711-11-20

Santos, R.S.; Santos, R. X.; Marisco, G. (2017). Avaliação da atividade genotóxica, citotóxica e antimicrobiana da infusão das folhas de Spondias purpurea L. Scientia plena, 13, p. 1-9. https://doi:10.14808/sci.plena.2017.039901

Sturbelle, R.T.; Pinho, D.S.; Restani, R.G. et al. (2010). Evaluation mutagenic and antimutagenic activity of Aloe vera in Allium cepa test and micronucleus test in human binucleated lymphocytes Brazilian. Journal of pharmacognosy, 20, p.409-415. https://doi.org/10.1590/S0102-695X2010000300019

Treusch, S. Hamamichi, Goodman, S.J et al. (2011). Functional links between A $\beta$ toxicity, endocytic trafficking, and Alzheimer's disease risk factors in yeast. Science, 334, p. 1241-5. https://doi: $10.1126 /$ science. 1213210

Vicente, M.F.; Basilio, A.; Cabello, A. et al. (2003). Microbial natural products as a source of antifungals. Clinical Microbiology and Infection, 9, p. 15-32. https:// doi:10.1046/j.1469$\underline{0691.2003 .00489 . x}$ 
Vieira, A.J.H; Santos, J.I. Mecanismos de resistência de Candida albicans aos antifúngicos anfotericina B, fluconazol e caspofungina. Revista Brasileira de Análises Clínicas, 49, p.235239, 2017. https://doi:10.21877/2448-3877.201600407

Zore, G.B.; Thakre, A.D.; Jadhav, S. et al. (2011). Terpenoids inhibit Candida albicans growth by affecting membrane integrity and arrest of cell cycle. Phytomedicine, 18, p. 1181-1190. https://doi.org/10.1016/j.phymed.2011.03.008

\section{Financing}

This study was funded by CNPq.

Interest conflicts

All authors declare no conflict of interest.

Ethics Committee Approval

Not applicable.

\section{Search data availability}

All data generated or dissipated in this study are included in the manuscript.

\section{Authors' contributions}

Idealization: Marisco, G; Methodology and data curation: Amorim, M, Souza, R; Formal analysis: Xavier, R, Asunción, R, Pungartnik, C; Writing - proofreading and editing: Marisco, G. 